\title{
THE FORMATION OF CUSTOMER CSR PERCEPTIONS IN THE BANKING SECTOR: THE ROLE OF COHERENCE, ALTRUISM, EXPERTISE AND TRUSTWORTHINESS
}

\author{
Andrea Pérez \\ Universidad de Cantabria \\ Ignacio Rodríguez del Bosque \\ Universidad de Cantabria
}

\begin{abstract}
The purpose of the authors in this paper is twofold. First, we aim to broaden the scope of analysis in the CSR-customer domain by testing the multidimensionality of CSR perceptions. We also define the role of CSR coherence, corporate altruism, expertise and trustworthiness in the formation of customer CSR perceptions. Results demonstrate that both altruism and CSR coherence directly influence CSR perceptions because of the scepticism of customers towards CSR. Corporate credibility dimensions -expertise and trustworthiness- have significant different effects on the formation of customer CSR perceptions so our results corroborate the necessity of analyzing these two dimensions as different concepts which affect corporate image in diverse ways.
\end{abstract}

Keywords: CSR Perceptions; CSR Coherence; Altruism; Expertise; Trustworthiness.

\section{INTRODUCTION}

For the purpose of enhancing corporate images and reputations, corporate social responsibility (CSR) has recently become an essential activity in the agenda of many companies worldwide. As an example of this commitment to societal concerns, companies implement codes of ethical behaviour, publish CSR reports periodically, exhibit their support to international CSR standards and work to be included in prestigious sustainability indexes such as the Dow Jones Sustainability Index or the FTSE4Good Index.

In the academic realm, the recent interest in CSR has derived into an extensive line of research concerning CSR perceptions (CSR image) and their influence on stakeholder behaviour. Researchers have been especially interested in determining how CSR image influences the identification of customers with the organization, their satisfaction with the company

2 Corresponding author: Avda. Los Castros s/n, 39005, Santander, Cantabria, Spain. perezran@unican.es. Tel: +942201661, Fax: +942201890 . 
or customer loyalty (Lichtenstein et al., 2004; Sen et al., 2006; Marín and Ruiz, 2007). Nevertheless, significantly lower attention has been paid to the study of the mental patterns that take customers to form CSR perceptions of businesses (Rifon et al., 2004; Becker-Olsen et al., 2006; Bigné et al., 2010). Furthermore, in this nascent domain researchers have concentrated on analyzing only limited representations of CSR -mostly cause-related marketing (CrM) and the sponsorship of social causes. However, the CSR definition has evolved since the initial conceptualizations provided in the 1950s and 1960s and this is now considered as a broader concept which includes a vast array of social initiatives aimed at positively affecting not only society but also other stakeholders such as customers, employees and shareholders (Maignan and Ferrell, 2004). This is, for example, the case with the banking industry which is analysed in this research.

As a consequence of the current financial crisis, the banking sector is now facing a significant loss of credibility and the trust of most of its stakeholders. CSR in this context tends to significantly raise stakeholder suspicion and, thus, customers might find it difficult to easily accept this new strategy as an altruistic commitment of the organization. Thus, reasons exist to believe that significant different patterns take customers to form a CSR image of their main banking providers when results are compared to previous findings in other industries (Pérez and Rodríguez del Bosque, 2012). Nevertheless, no paper has analyzed customer CSR perceptions in this industry so far, a fact which encourages the proposal of our research.

Based on these ideas, the goals of this paper are twofold: a) to test a multidimensional definition of CSR to understand customer CSR perceptions in the Spanish banking industry and b) to provide a causal model to explain the formation of CSR perceptions, which should allow the researchers to extend on previous findings by more clearly defining the role of CSR coherence, altruism and the dimensions of corporate credibility -expertise and trustworthiness- on CSR perceptions. For this purpose, the paper presents the results of two studies, each one oriented to analyze one of the objectives presented here. As the background for the research, first the definition of CSR in the banking industry is presented and, afterwards, the variables influencing the formation of customer CSR perceptions are introduced. The methodology section includes the research design of the two studies developed along with a discussion of the results. Finally, the most significant conclusions of the paper are commented.

\section{THE DEFINITION OF CSR IN THE BANKING SECTOR}

"We have long known that solid reputations not only reflect the quality, reliability, design, price and delivery of products and services but also spring from stakeholders' impressions of marketers' competence and authority, and their commitment and visibility in relation to financial, workplace, environmental and community issues" (Flyvholm and Isaksson, 2008). This is most obviously the case with the providers of banking services from which purchases are typically infrequent and long-term and often without immediate pay-offs or gratification for customers. Furthermore, banking products and services are usually perceived as generic and undifferentiated, and little inclination should be expected among customers to try to process more than a minimum of technical information in order to better understand and appreciate the complexity of this kind of companies. Thus, most of corporate image strategies, such as CSR, 
are more reliable than product disclosures for the generation of positive corporate images, reputations and trust in the current banking sector (Flyvholm and Isaksson, 2008).

Based on these ideas, financial providers such as banks and building societies have long invested in CSR strategies. In the international realm, for example, there has been a general adoption of CSR principles along with a growing investment in social initiatives. Furthermore, banking institutions have traditionally had the most links to the United Nations Global Compact, representing $9.48 \%$ of a total of 3,700 subscribing businesses in 2008 (CECA, 2008). Similarly, banking institutions are also present in the main sustainability indexes, accounting for more than $11 \%$ of the companies in the FTSE4Good Index and nearly $22 \%$ of the companies in the Dow Jones Sustainability Index. In Spain, most sustainability reports are published by the banking sector and $84 \%$ of institutions publish at least one annually (KPMG, 2008).

Nevertheless, still not enough research has been devoted to analyze the definition and articulation of CSR in this industry. In this regard, quite frequently companies implement isolated and incongruent initiatives which are not fully integrated in a solid CSR program which should derive from a clear definition of CSR in the banking sector. As a consequence, researchers and practitioners have usually equated CSR with visible and easily identifiable social initiatives such as cause-related marketing (CrM) or the sponsorship of social causes (Rifon et al., 2004). However, a significantly larger number of CSR dimensions have been implemented in the banking industry since the appearance of the concept and the CSR definition should be broaden so as to include new business perspectives and strategies. The proposal of the authors in this paper is to understand current CSR strategies in the banking industry based on the ideas provided by stakeholder theory. This perspective considers that CSR embeds corporate responsibilities towards the most influential audiences of the organization. In this regard, Clarkson (1995) believes that, because stakeholders are the main targets that businesses need to please, they should also be the focus of CSR initiatives. In this regard, Server and Capó (2009) state that companies comply with their social responsibility when they incorporate their stakeholder expectations into their strategic management. Furthermore, Sarro et al. (2007) believe that the involvement of banking institutions in CSR initiatives is the answer to ensuring the commitment of these entities to society such that it goes far beyond economic obligations to shareholders and also includes responsibilities towards other stakeholders such as employees, customers, suppliers, governments, investors or local communities. Taking these ideas into consideration, CSR in the banking industry could be defined as the set of corporate activities which demonstrate "the inclusion of social, economic and environmental concerns in business operations, and in interactions with stakeholders, also according to the ambition levels of corporate sustainability" (van Marrewijk, 2003).

Thus, based on stakeholder theory researchers have identified several CSR dimensions in the banking industry: customers, employees, shareholders, society, the environment, and a general dimension including all legal and ethical responsibilities of corporations. In the analysis of customer perceptions, the studies of Maignan et al. (1999) and Mercer (2003) stand out because they show that customers correctly understand these CSR dimensions and apply them in their evaluations of corporate actions. Study 1 in this paper is oriented to test this multidimensional structure in the current CSR strategies of banking institutions in Spain. 


\section{THE FORMATION PROCESS OF CSR IMAGE}

Furthermore, literature also demonstrates that customer CSR perceptions are directly influenced by the affect that CSR initiatives evoke in the individual. Thus, different emotional circumstances mediate the transfer of the positive image of a CSR initiative to a brand. In this paper, Study 2 proposes a causal model which will allow practitioners and researchers to anticipate the formation process of CSR image based on CSR coherence, altruism and corporate credibility dimensions (expertise and trustworthiness). Each of these concepts is explained in this section while the causal model is developed in the methodology section.

\subsection{CSR coherence}

First, the coherence, congruence, fit or relatedness between the company and its CSR activities is an especially relevant issue in the formation of customer CSR perceptions. CSR coherence refers to customer perceptions of the similarity between the company, its products, branding, positioning and target audiences, on the one hand, and the needs of the social initiatives and groups involved in them, on the other (Nan and Heo, 2007). Such consistency could be of different types depending on the comparative dimension that is referenced. The most common classification differentiates between functional and symbolic fit. The former refers to the compatibility between the product and the social cause, which is determined by a comparative analysis of the characteristics, attributes or functions of the marketed product and the characteristics and intentions expressed in the CSR initiative. On the contrary, symbolic fit represents the similarity between corporate personality and CSR initiatives, which is based on the existence of a symbolic link between both (such as the existence of the same features in their image, positioning and goals). In the banking sector CSR is implemented as a global strategy which includes a broad array of issues aligned with the stakeholder theory. In this case, it should be noted that these initiatives are generally independent of the type of service delivered by the entity and they are quite often presented globally in emotional advertisements on mass media. Therefore, the study of the consistency of the CSR with the service should not be relevant to identify significant patterns in the image formation process while the effects of symbolic CSR coherence are expected to be stronger.

\subsection{Altruism}

Furthermore, CSR has traditionally been conceived as a utilitarian strategy. For companies, their belief "the greatest good of the greatest number" justifies the corporate alignment with social causes. Bigné et al. (2010) consider that customers, however, are not so utilitarian and that they pay attention not only to the social effects of CSR but also to the motivations for it. "In fact, they (customers) judge CSR suitability not on the basis of its consequences (e.g., the company donates a large amount of money to the social cause) but on the basis of the motivations behind the company's association with the social cause" (Bigné et al., 2010).

Motivational attribution is the result of a cognitive process by which the individual assigns a cause for an observed situation. Researchers identify two types of motivations that an individual can perceive in the activities of a company. The first type focuses on the potential benefits that external stakeholders, such as customers and society, will obtain from the 
company's activities. These motivations are altruistic. A second group of motivations focuses on the potential benefit the company will obtain, which is perceived as closely related to the company's private objectives. These motivations are egoistic (Gwinner, 1997; Forehand and Grier, 2003). Because customers can perceive mixed motivations on a company's engagement in CSR, both altruism and egoism are usually conceived as extremes of the same continuum. Attribution theory defends that customers simultaneously attribute egoistic and altruistic motivations in CSR programs and that they will discount the effect of one of them when alternative motivations are more feasible. Thus, it is the predominance of altruism or egoism which especially affects customer assessments of corporate motivations on CSR. Furthermore, and based on the virtue ethics perspective, van de Ven (2008) suggests that CSR activities can only be considered virtuous if they satisfy a genuine motivation of the company rather than an egoistic interest. Thus, the attribution of altruistic motivations generates positive responses from the customer and is the perception that companies should try to promote.

\subsection{Corporate credibility: expertise and trustworthiness}

Finally, it is also necessary to highlight that, although customers are willing to support socially responsible companies, they are usually sceptical about CSR initiatives. Thus, businesses need to counteract the negative expectations by promoting their credibility in their CSR endeavours. Corporate credibility is a multidimensional concept whose components, however, have only recently been given independent consideration. When it comes to CSR, only Bigné et al. (2010) have provided some sort of advancement in the understanding of how credibility dimensions influence customer CrM perceptions. In this regard, credibility in the context of CSR refers to the degree to which a customer perceives that the company is skilled and experienced in the development of CSR programs (expertise) and believes that it expresses sincerity and honesty when doing so (trustworthiness) (Bigné et al., 2010). These source qualities, if communicated effectively to corporate stakeholders, will evoke and strengthen the company's authority and reputation, two of the most salient goals of corporate brands nowadays. In this regard, it is believed that both corporate expertise and trustworthiness legitimize the business institution when it links up to social causes. It has been demonstrated that, when faced with CSR communications, customers put in motion a series of cognitive processes which follow a 'guarantee acquisition' rationale to legitimate the company as a socially responsible organization. The perception of the organization as honest and competent is the basic judgment underpinning this legitimation.

\section{METHODOLOGY}

This section is divided into two studies, each one oriented to cover one of the research goals proposed in this paper.

\subsection{Study 1 - CSR multidimensionality}

In Study 1, the first purpose of this paper is covered. The authors test and validate the multidimensionality of CSR perceptions in the banking industry. 


\section{(a) Research design}

A quantitative study based on interviewer-administered surveys of Spanish banking service customers was designed. A multi-stage sampling by quotas was used to design the research sample based on customer gender and age. The field work was performed in April 2010, and after the collection and processing of the information, a total of 1,124 valid surveys remained (response rate $=93.67 \%$ ). The sample was $48.52 \%$ male and $51.48 \%$ female, which was comparable to the representative population of the country with $49.03 \%$ female and $50.97 \%$ male. Regarding age, customers in the sample were $46.62 \%$ under 44 (50.14\% in the national population), $31.70 \%$ between 45 and 64 (29.68\% in the national population) and $21.69 \%$ over $64(20.19 \%$ in the national population). It is also interesting that there exist 2 significantly different types of banking institutions in the Spanish market, banks and building societies, which exhibit diverse approaches to CSR (Pérez and Rodríguez del Bosque, 2012). Based on this fact, the sample is divided into bank and building society customers and the validation of the scale is independently undertaken for both samples. 476 surveys were gathered for bank customers and 648 surveys for building society customers.

\section{(b) Scale development}

The multidimensionality of the scale was conceptualized based both on a literature review and a qualitative exploratory research including in-depth interviews with the CSR and Reputation managers of some of the most important Spanish banks and building societies ${ }^{1}$. The former CEO of one of the banks in the study (BBVA) defined four key stakeholders in the CSR policy of his bank: shareholders, customers, employees and society (Goirigolzarri, 2006). The fourth vice-chairman of another corporation (Santander), states that a bank must acquire an ethical commitment to all the stakeholders that are affected by corporate behaviour including shareholders, employees, customers, suppliers, governments and society (Soto, 2006). Furthermore, Sarro et al. (2007) assert that, in the banking industry, suppliers and customers could be considered as one single stakeholder because customers supply banking institutions with money, the essential input in this industry. The qualitative study demonstrated that all the analyzed institutions use stakeholder theory in the disclosure of their CSR policies in annual CSR reports and on the Internet. This research also revealed that, though building societies do not have shareholders because of their legal status, they still have to report to their supervising boards, which evaluate their results and take investment decisions. After this first step, five dimensions were identified as relevant for the CSR image of a banking institution: customers, shareholders and supervising boards, employees, society and a general dimension encompassing legal and ethical issues of the banking institutions.

In a second phase, items related to each dimension were generated through a literature review. First, items CSRImg1 to CSRImg5 refer to corporate activities oriented towards customers, basically concerning complete and honest communication regarding corporate products and services as well as in the management of complaints. All of these items were taken from

\footnotetext{
Six CSR and Reputation managers of national banks and building societies were interviewed. The banks studied were Santander and BBVA, and the building societies were Caja Madrid, La Caixa, Caja Cantabria and Caja Navarra.
} 
previous papers by Maignan et al. (1999) and García de los Salmones et al. (2005). Items CSRImg6 to CSRImg8 are related to corporate responsibilities towards shareholders and supervising boards, basically referred to corporate profitability. Items CSRImg9 to CSRImg13 were taken from Mercer and relate to responsibilities towards employees. These 5 items cover issues regarding job creation and employment opportunities. Next, corporate obligations towards society are represented in items CSRImg14 to CSRImg19 and refer to issues such as charity, community development or environmental protection. Finally, items CSRImg20 to CSRImg22 include ethical and legal concerns related to general corporate responsibilities that do not benefit any one stakeholder specifically but equally impact all of them. This dimension had already been tested and confirmed by Maignan, so items were taken from previous papers by this Dutch author.

Table 1: CSR image scale

Ítem (I believe that this company...)

CSRImg1. ...establishes procedures to comply with customers' complaints

CSRImg2. ... treats its customers honestly

CSRImg3. ...has employees that offer complete information about corporate products/ services to customers

CSRImg4. ...uses customers' satisfaction as an indicator to improve the product/ service marketing

CSRImg5. ...make an effort to know customers' needs

CSRImg6. ...tries to maximize its profits

CSRImg7. ...keep a strict control over its costs

CSRImg8. ...tries to insure its survival and long-term success

CSRImg9. ...pay fair salaries to its employees

CSRImg10. ...offer safety at work to its employees

CSRImg11....treats its employees fairly (without discrimination or abuses)

CSRImg12....offers training and career opportunities to its employees

CSRImg13. ...offers a pleasant work environment (e.g. flexible hours, conciliation)

CSRImg14. ...helps solving social problems

CSRImg15. ...uses part of its budget for donations to advance the situation of the most unprivileged groups of the society

CSRImg16. ...contributes money to cultural and social events (e.g., music, sports)

CSRImg17....plays a role in the society beyond the economical benefits generation

CSRImg18. ...is concerned with improving the general well-being of society

CSRImg19....is concerned with respecting and protecting the natural environment

CSRImg20. ...always respects rules and regulations defined by law

CSRImg21. ...is concerned with fulfilling its obligations vis-à-vis its shareholders, suppliers and other agents

CSRImg22. ...is committed to well established ethic principles

Notes: 7 -point Likert-scale (1=strongly disagree with the sentence; $7=$ strongly agree) 


\section{(c) Results}

To test the multidimensionality of customer CSR perceptions, first the psychometric properties of the scale (reliability and validity) were evaluated. For this purpose, a first-order confirmatory factor analysis (CFA) was performed according to the maximum robust likelihood estimation procedure, using the statistical software program EQS 6.1. (Table 2). The reliability of the proposed measurement scale was evaluated using Cronbach's alpha $(\alpha)$ and the Average Variance Extracted (AVE). The values of these statistical parameters are above the minimum recommended values of 0.7 and 0.5 in both samples, thus confirming the internal reliability of the proposed construct. In addition, all the items are significant to a confidence level of $95 \%$ and their standardized lambda coefficients are greater than 0.5 , which confirms the convergent validity of the model. We verified discriminant validity and confidence intervals for the correlation of the constructs, obtaining and comparing them with the unity. None of the intervals contained this value, thus confirming that the proposed measurement model is correct. Finally, the goodness-of-fit of the analysis was measured with the Chi-square statistic (Satorra-Bentler) and the Comparative Fit Indexes (NFI, NNFI, CFI and IFI) because they are the most common measures in CFA and Structural Equation Modeling (SEM). Although the Chi-square is significant in both samples $(\mathrm{p}<0.05)$, this result can be a consequence of the large size of the samples (over 200 cases). So, we completed the analyses with the Comparative Fit Indexes, which were in all cases close to or above 0.9 , thus confirming the good fit of the model to the collected data. Second-order CFAs were also performed to test whether CSR dimensions converged in a single CSR image construct. Once again, the values of the Chisquare were significant but the comparative fit indexes confirmed the validity of the proposed scale for both banks' and building societies' CSR image ${ }^{2}$.

Thus, the results of Study 1 confirm the multidimensionality of customer CSR perceptions in the banking industry. In this regard, the 5-dimension structure proposed in this paper is valid and reliable to evaluate the CSR perceptions of customers of both banks and building societies. These organizations have had traditionally different approaches to CSR (Pérez and Rodríguez del Bosque, 2012) and this fact claims for the strength of the measurement tool proposed in this paper.

\subsection{Study 2 -Customer formation of CSR image}

Once the dimensionality of CSR perceptions in the banking industry is confirmed, the purpose in this second study is to develop and validate a causal model which helps practitioners and researchers to better understand the role of CSR coherence, corporate altruism, expertise and trustworthiness in the formation of customer perceptions of CSR. First, the model is developed. Afterwards, the methodology is presented and the results are discussed.

2 Banks: $\mathrm{S}-\mathrm{B} \chi 2=430.64(\mathrm{p}=.00) ; \mathrm{NFI}=.91 ; \mathrm{NNFI}=.94 ; \mathrm{CFI}=.95 ; \mathrm{IFI}=.95$; Building societies: $\mathrm{S}-\mathrm{B} \chi 2=359.57(\mathrm{p}=.00) ; \mathrm{NFI}=.89$; $\mathrm{NNFI}=.94 ; \mathrm{CFI}=.95 ; \mathrm{IFI}=.95$ 


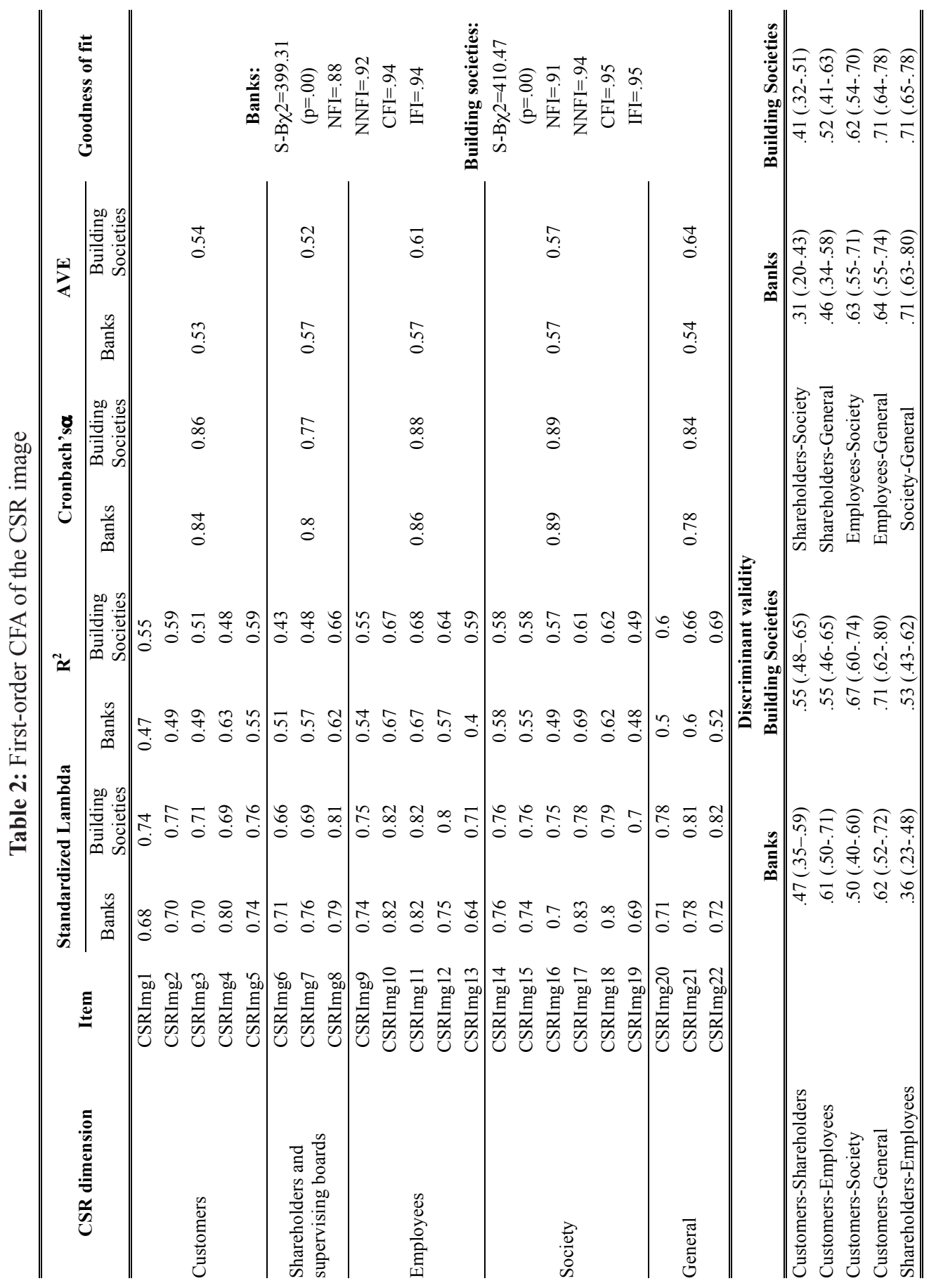




\section{(a) Hypotheses development}

First, schemas theory and the studies on associative memory networks, based on associative learning ideas, traditionally explain the effects of CSR coherence on the cognitive processes of the customer (Lynch and Schuler, 1994; Roy and Cornwell, 2003). According to these theories, learning is a mechanism by which people establish relationships between concepts to produce an associative network in their memory. Through this network, customers learn about a concept by its relationship to other nodes in their memory. In the field of CSR, these stimuli are social causes, non-profit organizations or institutions related to the promotion of social projects in the business arena. The learning process will also be more solid and fruitful for the company if it maintains stable and consistent links with these agents. Thus, the organization will enhance its public image as it develops CSR policies consistent with its personality. However, Rifon et al. (2004) indicate that some important elements of the associative learning theories are not yet clear. The study of what motivates an organization to engage in CSR offers a valuable perspective to fill unclear areas of this approach. In their quest for success in the marketplace, companies should consider customer explanations of these motivations. CSR performance is open to inquiry regarding its underlying reasons, and it is possible that the resulting causal inferences affect customer intentions.

Specifically, first there is a possibility that the coherence of CSR strategies has a direct effect on the attribution of motivations by the customer. Thus, following the model proposed by associative learning theories, Rifon et al. (2004) confirm that the fit between the business and sponsored social causes generates an allocation of stronger altruistic motivations on the part of the customer. Ellen et al. (2006) also suggest that a greater compatibility between the goals of a sponsored social cause and the core business of the organization can make the allocation of strategic, value-based motivations more feasible while decreasing the perception of egoistic motivations on the part of the company. Therefore, when the coherence is high, CSR initiatives seem to be a direct result of the willingness of the organization to help the social cause and strengthen relationships with customers rather than its interest in obtaining economic benefits:

H1: CSR coherence directly and positively influences altruism.

Furthermore, CSR coherence can also influence corporate credibility dimensions. If a customer perceives that the CSR of a company is consistent with its own personality, then he/she is likely to consider the CSR program credible because the connection between the organization and its CSR initiatives is easily understood and integrated in the mental schema of the customer. In contrast, if CSR activities are not consistent with the identity that the organization is trying to convey, the amount of effort the customer must expend in understanding CSR will reduce customer perceptions of corporate expertise and trustworthiness in the development of the CSR program of the company. This line of reasoning is provided by schema and associative learning theories (Till and Nowak, 2000). According to these perspectives, when there is high CSR coherence the customer does not have to mobilize cognitive resources to evaluate corporate initiatives. This fact reduces the likelihood of suspicion appearing over the honesty and expertise of the brand in its relation with the social cause. Several empirical studies have also positively tested this hypothesis (Rifon et al., 2004; Becker-Olsen et al., 2006). Nevertheless, this proposal has barely been applied to the study of different dimensions of 
corporate credibility (Bigné et al., 2010). Based on these ideas, two new research hypotheses are proposed:

H2: CSR coherence directly and positively influences corporate expertise.

H3: CSR coherence directly and positively influences corporate trustworthiness.

Likewise, a direct positive relationship should be expected between altruism and corporate expertise and trustworthiness. Attribution theory justifies this proposal (Weiner, 1980). This theory describes people as rational information processors whose actions are influenced by the causal inferences they make about observed events. Thus, because of the impossibility of knowing all the information about an event, customers try to infer that information to determine why the event occurred. In terms of CSR, the theory proposes that altruistic motivations can form the basis of the corporate credibility and customer positive attitudes towards the company. Conversely, the attribution of firm self-serving motivations creates a less favourable corporate image. Rifon et al. show that if the person perceives the existence of altruistic motivations on behalf of the company, the effects of CSR coherence on corporate credibility may increase. Similarly, Becker-Olsen et al. show that the allocation of social motivations may counteract the negative effect of a low fit between the company and the social causes it supports. According to these arguments, two new research hypotheses read as follows:

H4: Altruism directly and positively influences corporate expertise.

H5: Altruism directly and positively influences corporate trustworthiness.

Recent circumstances in the international business realm also take the researchers of this paper to believe in a stronger effect of both CSR coherence and altruism on CSR image. Basically, CSR investments are significantly increasing nowadays. However, the rising social pressure for companies to incorporate these kinds of activities into their agendas, as well as the massive increase in CSR communications, raise suspicion about the reasons that lead companies to implement these strategies and about the sincere incorporation of CSR into their corporate identities. Furthermore, most of the current criticism laid on businesses derives from their CSR communications because CSR initiatives are perceived as utilitarian green-washing strategies. Pomering and Johnson (2009) point to the scepticism of society as a direct consequence of CSR communications. Thus, customers more carefully evaluate business activities nowadays and the single perception of corporate inconsistencies or utilitarian purposes will have a direct negative effect on corporate image. Nevertheless, researchers have not proved these hypotheses so far.

In this regard, Ellen et al. (2006) suggest that, along with the effects of CSR initiatives on customers, the intermediate processes in the formation of the CSR image (CSR coherence and altruism) can also influence the success or failure of CSR strategies. First, according to the associative learning theory, a high level of association between the personality of the company and its CSR can improve customer attitudes toward the company and its brands as the customer believes corporate activities to be appropriate. Therefore, a good fit between the company and its CSR program will be more easily integrated in the customer associative network, strengthening the perception of a positive relationship between the company and its CSR initiatives (Menon and Kahn, 2003). Furthermore, Barone et al. (2000) show that 
customers prefer brands that exhibit altruistic motivations in the support of social causes. In contrast, with some CSR activities, the company might be the main beneficiary and, then, be considered as an exploiter of the social cause.

H6: CSR coherence directly and positively influences CSR image.

H7: Altruism directly and positively influences CSR image.

Finally, practitioners truly believe in a strong relationship between corporate credibility, CSR and public image. Specifically, corporate credibility is an essential factor in building brand value through CSR (Hoeffler and Keller, 2002). Recent literature points to the significant role played by the source of the message when determining customer responses to marketing activities and business communication processes. Thus, various theories, such as the theory of persuasion, the cognitive response theory and the theory of reasoned action propose that an expert and reliable source is more persuasive than a source perceived as less reliable. The lack of credibility leads customers to question the validity of the statements made by the source which, in the case of a company and its customers, translates into a negative effect on purchase intention. For example, Lafferty and Goldsmith (1999) show that a high level of corporate credibility causes customers to form a positive attitude towards a company and it increases their purchase intentions. Similarly, Goldsmith et al. (2000) confirm that customers exposed to an ad from a highly credible company develop better attitudes toward the brand. In the CSR field, Hoeffler and Keller (2002) state that brand credibility is a necessary antecedent to build brand value through social marketing. Based on the distinction established in this paper between corporate expertise and trustworthiness, the last two hypotheses of the research are proposed:

H8: Corporate expertise directly and positively influences CSR image.

H9: Corporate trustworthiness directly and positively influences CSR image.

The model proposed in this paper is represented in Figure 1.

Figure 1: Conceptual model

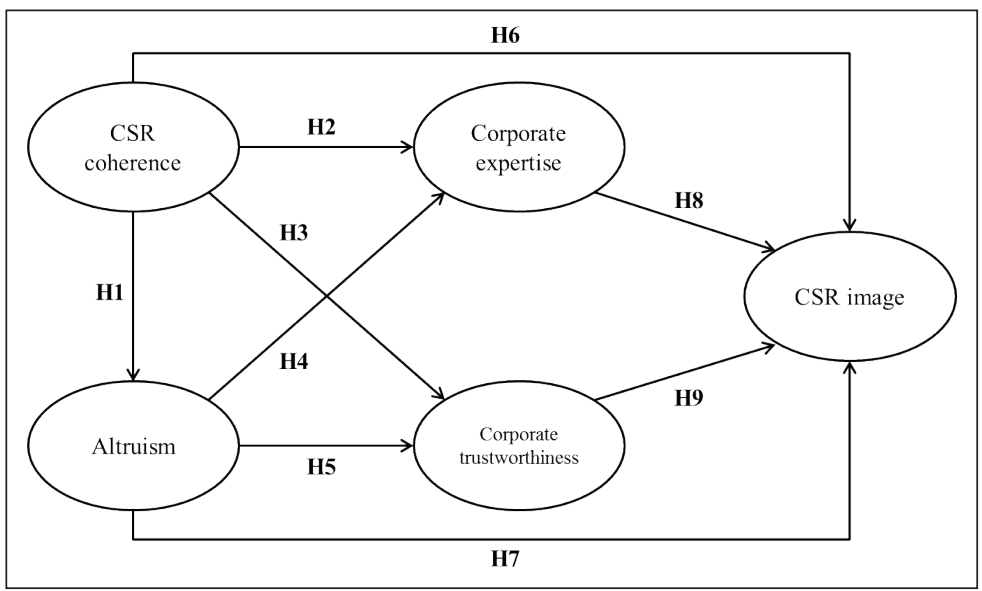




\section{(b) Research design}

To test the research hypotheses, SEM is implemented using EQS 6.1.. The sample collected in Study 1 (476 bank customers and 648 building society customers) is used for this purpose.

\section{(c) Measurement scales}

CSR coherence, corporate altruism, expertise, trustworthiness and CSR image were measured using 7-point Likert-type multidimensional scales (1 indicates "strong disagreement with the statement" and 7 indicates "strong agreement with the statement"). First, a 4-item scale based on previous proposals by Lafferty et al. (2004) and Bigné et al. (2010) was developed to measure CSR coherence, defined as the symbolic link between corporate personality and the CSR policy of the organization. In designing the 4-item scale for measuring altruism, the works of Becker-Olsen et al. (2006) and Bigné et al. (2010) were taken as references. Corporate credibility was explained by two components based on papers by Newell and Goldsmith (2001) and Lafferty (2007). Corporate expertise (2 items) indicates the skill and competence demonstrated by the company in the implementation of its CSR policy. Perceived trustworthiness ( 2 items) refers to the confidence offered by the company when managing its CSR - e.g., the company is perceived as an organization that "you can rely on". Finally, CSR image was measured by applying the scale validated in Study 1 to this second phase of the research.

Table 3: Measurement scales

\section{CSR coherence}

Coher1. Carrying out CSR activities is compatible with (X)'s core business

Coher2. It makes sense that $(X)$ carries out CSR activities

Coher3. Carrying out CSR activities is complementary to (X)'s core business

Coher4. There is a logical fit between (X)'s core business and the CSR activities that it carries out

\section{Altruism}

Altru1. (X) acts unselfishly

Altru2. (X) is altruist

Altru3. (X) acts guided by the global benefit of its stakeholders instead of by its self-interest

Altru4. (X) is generous

\section{Corporate expertise}

Exper1. (X) has a great expertise in CSR

Exper2. (X) is competent in the implementation of its responsibilities towards its stakeholders

\section{Corporate trustworthiness}

Trust1. (X)'s commitment with its stakeholders is credible

Trust2. $(\mathrm{X})$ is honest about its commitment with its stakeholders

Note: 7 -point Likert-scale ( $1=$ strongly disagree with the sentence; $7=$ strongly agree) 


\section{(d) Results}

A first-order CFA analysis was performed to test the goodness of fit of the model for the formation process of CSR image. Reliability of the scales as well as their convergent and discriminant validity were also tested (Tables 4 and 5). The Comparative Fit Indexes NFI, NNFI, CFI and IFI- in all cases exceeded the minimum recommended value of 0.90 , demonstrating a good fit of the model. In addition, the standardized lambdas obtained for the latent concepts (CSR coherence, altruism, expertise, trustworthiness and CSR image) were

Table 4: First-order CFA of the global model of CSR image

\begin{tabular}{|c|c|c|c|c|c|c|c|c|c|}
\hline \multirow[t]{2}{*}{ Factor } & \multirow[t]{2}{*}{ Item } & \multicolumn{2}{|c|}{$\begin{array}{l}\text { Factor } \\
\text { loading }\end{array}$} & \multicolumn{2}{|c|}{$\mathbf{R 2}$} & \multicolumn{2}{|c|}{$\begin{array}{c}\text { Cronbach's } \\
\boldsymbol{\alpha}\end{array}$} & \multicolumn{2}{|c|}{ AVE } \\
\hline & & $\mathbf{B}$ & BS & B & BS & B & BS & B & BS \\
\hline \multirow[t]{4}{*}{ CSR coherence } & Coher1 & .81 & .86 & .66 & .74 & .88 & .89 & .64 & .68 \\
\hline & Coher2 & .89 & .87 & .79 & .76 & & & & \\
\hline & Coher3 & .70 & .82 & .49 & .68 & & & & \\
\hline & Coher4 & .80 & .74 & .64 & .55 & & & & \\
\hline \multirow[t]{3}{*}{ Altruism } & Altru1 & .83 & .84 & .69 & .71 & .85 & .81 & .66 & .60 \\
\hline & Altru2 & .79 & .71 & .63 & .51 & & & & \\
\hline & Altru3 & .82 & .76 & .67 & .58 & & & & \\
\hline \multirow[t]{2}{*}{ Corporate expertise } & Exper1 & .77 & .82 & .59 & .69 & .84 & .85 & .73 & .74 \\
\hline & Exper2 & .93 & .90 & .86 & .80 & & & & \\
\hline \multirow[t]{2}{*}{ Corporate trustworthiness } & Trust1 & .89 & .91 & .79 & .82 & .87 & .88 & .77 & .78 \\
\hline & Trust2 & .86 & .86 & .74 & .74 & & & & \\
\hline \multirow[t]{5}{*}{ CSR image (customers) } & Customers & .68 & .73 & .47 & .53 & .81 & .85 & .48 & .54 \\
\hline & Shareholders & .51 & .61 & .30 & .37 & & & & \\
\hline & Employees & .69 & .72 & .48 & .51 & & & & \\
\hline & Society & .75 & .79 & .57 & .62 & & & & \\
\hline & General & .77 & .80 & .60 & .64 & & & & \\
\hline
\end{tabular}

Notes: Goodness of fit indexes: S-B $\chi 2(109)=212.60-234.33(\mathrm{p}=0.00) ; \mathrm{NFI}=.93-.95 ; \mathrm{NNFI}=.96 ; \mathrm{CFI}=.97$; $\mathrm{IFI}=.97 ; \mathrm{RMSEA}=.04$

Table 5: Discriminant validity

\begin{tabular}{ccccccccccc}
\hline & \multicolumn{2}{c}{ Coh } & \multicolumn{2}{c}{ Alt } & \multicolumn{2}{c}{ Exp } & \multicolumn{2}{c}{ Trust } & \multicolumn{2}{c}{ CRS } \\
\cline { 2 - 11 } & B & BS & B & BS & B & BS & B & BS & B & BS \\
\hline Coh & - & - & .26 & .25 & .56 & .59 & .48 & .44 & .38 & .48 \\
Alt & {$[.15-.37][.16-.34]$} & - & - & .44 & .46 & .61 & .57 & .46 & .47 \\
Exp & {$[.46-.66][.52-.66]$} & {$[.34-.54]$} & {$[.38-.54]$} & - & - & .82 & .79 & .40 & .57 \\
Trust & {$[.38-.58][.35-.53]$} & {$[.53-.69][.50-.64]$} & {$[.75-.89][.73-.85]$} & - & - & .53 & .52 \\
CSR & {$[.28-.48][.39-.57]$} & {$[.38-.54][.39-.55]$} & {$[.31-.49][.49-.65][.44-.62]$} & {$[.43-.61]$} & - & - \\
\hline
\end{tabular}

Notes: (1) Values above the diagonal represent the correlation between factors; (2) Values below the diagonal represent the $95 \%$ confidence interval for the correlation between factors. 
significant and greater than 0.50 , ensuring the convergent validity of the model. The results verified the discriminant validity of the model because no confidence interval included the value of the unit.

Once the validity of the measurement scales was successfully verified, the test of the hypotheses was performed with the statistical software EQS 6.1. The results of the analysis are shown in Table 6. First, the results confirm the proposed relationship between CSR coherence and altruism in both the banks and building societies samples. Thus, hypothesis H1 cannot be rejected. Furthermore, both CSR coherence and altruism are direct antecedents of corporate credibility dimensions, that is, corporate expertise and trustworthiness. Based on these results, then, hypotheses $\mathrm{H} 2$ to $\mathrm{H} 5$ are not rejected. These results allow us extending previous findings provided by authors such as Bigné et al. (2010). For example, these researchers consider that the symbolic dimension of CSR coherence mainly leads to improved perceptions of brand honesty instead of corporate expertise because "image fit" is a more symbolic, peripheral indicator which involves a lower degree of cognitive elaboration by consumers and, thus, image fit is likely to awaken more affective reactions to CSR in customers. In this regard, trustworthiness has been defined as the affective dimension of company credibility and it is related to consumer general feelings toward the company. Thus, the connection between both concepts is stronger than for corporate expertise. Nevertheless, in our paper we demonstrate these results only for the building societies sample but not for banks. Something similar happens when analyzing the effects of altruism in corporate expertise and trustworthiness. In this case, Bigné et al. (2010) consider that altruistic attribution does not necessarily influence the two company credibility dimensions with equal strength. According to these authors, altruism mainly indicates corporate honesty, sincerity, and goodwill when the company sponsors a social cause. These authors also based their reasoning on traditional literature on social psychology persuasion which shows that a source with no self-interest in the promoted

Table 6: Hypotheses testing

\begin{tabular}{ccccccc}
\hline \multirow{2}{*}{ Hypotheses } & Causal relationship & \multicolumn{2}{c}{$\begin{array}{c}\text { Std. } \\
\text { coefficient }\end{array}$} & \multicolumn{2}{c}{ T-value } & \\
\cline { 2 - 5 } & & B & BS & B & BS & \\
\hline H1 & Coherence $\rightarrow$ Altruism & .26 & .29 & $4.50^{*}$ & $3.25^{*}$ & Accepted \\
H2 & Coherence $\rightarrow$ Expertise & .48 & .31 & $6.84^{*}$ & $5.40^{*}$ & Accepted \\
H3 & Coherence $\rightarrow$ Trustworthiness & .35 & .43 & $5.73^{*}$ & $8.73^{*}$ & Accepted \\
H4 & Altruism $\rightarrow$ Expertise & .31 & .86 & $5.50^{*}$ & $5.37^{*}$ & Accepted \\
H5 & Altruism $\rightarrow$ Trustworthiness & .52 & .45 & $9.34^{*}$ & $4.94^{*}$ & Accepted \\
H6 & Coherence $\rightarrow$ CSR image & .17 & .05 & $2.64^{*}$ & .60 & Accepted $(\mathrm{p})^{1}$ \\
H7 & Altruism $\rightarrow$ CSR image & .24 & .15 & $3.72^{*}$ & $2.44^{*}$ & Accepted \\
H8 & Expertise $\rightarrow$ CSR image & .02 & .03 & .15 & .22 & \\
H9 & Trustworthiness $\rightarrow$ CSR image & .29 & .53 & $3.39^{*}$ & $7.55^{*}$ & Accepted \\
\hline
\end{tabular}

Notes: $* \mathrm{p}<0.05$; Goodness of fit indexes (banks): $\mathrm{S}-\mathrm{B} \chi 2(110)=214.75(\mathrm{p}=0.00) ; \mathrm{NFI}=.93$; NNFI $=.96$; CFI $=.97 ; \mathrm{IFI}=.97 ; \mathrm{RMSEA}=.04 ;$ Goodness of fit indexes (building societies): S-B $\chi 2(108)=566.58(\mathrm{p}=0.00)$; $\mathrm{NFI}=.86 ; \mathrm{NNFI}=.86 ; \mathrm{CFI}=.89 ; \mathrm{IFI}=.89 ; \mathrm{RMSEA}=.08 .{ }^{1}(\mathrm{p})=$ partially 
message appears more trustworthy and honest. Nevertheless, in our study this theory proves to be true only for bank customers while the opposite situation is given in the formation process of CSR image among customers of building societies. Thus, we conclude that the strength of hypotheses $\mathrm{H} 2$ to $\mathrm{H} 5$ is conditional upon the kind of enterprise analyzed, a fact not considered by previous researchers.

Regarding the direct effects that we initially assumed for CSR coherence and altruism on CSR image, the results confirm both relationships for bank customers. However, in the building societies sample only altruism directly influences CSR perceptions. Thus, while $\mathrm{H} 7$ is positively confirmed, H6 is only partially accepted. These results might be justified by the lower coherence perceived in the CSR strategies of building societies vs. banks (MeanBS=4.53; MeanB=5.67). In this regard, banks in Spain have significantly worked on aligning their CSR programs with their strategic management of stakeholders, which especially focuses on the advancement of customers and employees. On the contrary, building societies have kept investing mostly in charity and societal initiatives which are not directly related to their business scope and, thus, result in less coherent CSR initiatives (Pérez and Rodríguez del Bosque, 2012). This fact is perceived by customers who, consequently, do not directly link CSR coherence with their perceptions of CSR programs in the building societies sample. Again, these results confirm that the formation of CSR perceptions is significantly different among banks and building societies and, thus, not only diverse dimension of the constructs in the model should be analyzed but also the contextual character of CSR and customer perceptions should be bared in mind when explaining the consequences of CSR coherence, altruism, expertise and trustworthiness.

Finally, significantly different roles are observed for corporate credibility dimensions in the formation process of CSR image. In this regard, first it is observed that corporate CSR expertise does not influence CSR image to any extent, neither in the banks nor in the building societies samples. Based on these results, hypothesis $\mathrm{H} 8$ must be rejected. On the contrary, corporate trustworthiness positively influences CSR image so H9 cannot be rejected. With these two last results we not only accept but we are also able to extend previous findings in academic literature. In this regard, while Bigné et al. (2010) demonstrate that trustworthiness has more weight than expertise in judgments about CSR, we demonstrate that in the banking industry this fact is even stronger as corporate expertise in CSR does not influence customer CSR perceptions to any extent. This result can be explained by the lack of confidence that customers and society have demonstrated to have in banking providers after the global crisis. Thus, banking service users specially tend to trustworthiness when evaluating new initiatives undertaken by their institutions, CSR being a quite recent business strategy. Bigné et al. (2010) demonstrate these ideas using Balance Theory. According to this perspective, consumers will seek a balanced and harmonious set of beliefs around the brand, and they will be especially motivated to reconcile incongruent thoughts referred to the company. So, it is possible to posit that the potential scenario of company suspicion provoked by CSR strategies will be mainly corrected by perceptions of company honesty, sincerity and goodwill, which help customers to deactivate the feeling of manipulation. Thus, trustworthiness is finally a more useful and valuable cue than expertise in the evaluation of the social character of an organization. 


\section{CONCLUSIONS}

In this paper, authors have tried to more clearly define customer CSR perceptions in the banking industry, testing the dimensionality of the concept along with the particular process that users follow to form their perceptions. The most significant conclusions derived from the research are presented next.

First, it has been demonstrated that CSR in the banking industry is a multidimensional concept which includes significantly more dimensions than the typical CrM or sponsorship strategies usually equated to CSR by previous researchers. Specifically, CSR in the banking industry can be defined as the set of corporate initiatives which account for the economical, legal, ethical and philanthropic responsibilities of banking institutions towards their most significant stakeholders. CSR is divided in corporate responsibilities towards customers, employees, shareholders (and supervising boards) and the society, along with an additional dimension which gathers ethical and legal responsibilities globally. The scale allows us to understand perceptions among both banks and building societies customers. This result accounts for the robustness of the CSR dimensionality proposed in this paper which segments CSR based on stakeholder theory and the main audiences of banking institutions.

Furthermore, it has also been demonstrated that in the banking industry both CSR coherence and altruism have a strong effect on CSR image, mostly because of the loss of corporate credibility and stakeholder trust in their banking providers. The global economic crisis has especially affected banking institutions which are claimed to be guilty of the international recession. Thus, customers pay greater attention to the consistency of CSR initiatives and the motivations behind corporations. At the same time, they request better managerial tools to evaluate corporate behaviours. In such a context, inconsistencies with the personality of the organization or egoistic motivations raise the suspicion of stakeholders which worsen their evaluations of CSR in the banking industry.

Finally, it has been observed that the dimensions of corporate credibility -expertise and trustworthiness-, have a significantly different role in the formation of customer CSR perceptions. Thus, our paper aligns with the idea that corporate credibility should not be globally theorized in the banking industry and both corporate CSR expertise and CSR trustworthiness should be independently analyzed to better understand customer perceptions in this sector. In this regard, while trustworthiness directly and positively influences CSR image, customer perceptions are totally independent of the level of corporate expertise in the implementation of social initiatives. Again, stakeholder distrust in banks and building societies might be accounting for this result because suspicion takes individuals to especially care about corporate honesty and reliability. Furthermore, CSR initiatives have long been implemented in the banking industry so customers perceive institutions to be expert in this realm and expertise is no longer a differentiating feature in the evaluation of CSR in this sector.

Our results have significant implications for CSR and marketing practitioners. In this regard, previous scholars have demonstrated "an overwhelming focus in both text and images on recounting companies' achievements and competencies at the expense of providing assurance of their integrity, truthfulness or attention to clients' needs" (Flyvholm and Isaksson, 2008). There is also clear evidence that corporate advertising is in fact strongly focused 
on communicating credibility with less than 10 per cent of discourse and visuals devoted to credibility-free themes and issues. Thus, while projecting credibility is important for companies in the banking industry, they seem to be orienting their corporate communications in the wrong direction: significantly more attention should be paid to communicating corporate CSR trustworthiness instead of expertise because customers care more about this variable when evaluating banking providers. Further academic and managerial implications refer to the fact that a general causal model to understand the formation of customer CSR perceptions might not be found to properly explain customer behaviour in diverse industries. In this regard, we have observed significant differences in the information processing of banks and building societies customers while we also perceived inconsistencies with previous findings in different industries. Thus, the justifications provided by previous researchers when explaining the role of coherence, altruism, expertise and trustworthiness in the formation of CSR images need to be cautiously taken. We have demonstrated that differences do not only depend on the dimensions of the concepts analyzed (e.g., symbolic vs. functional or egoism vs. altruism) but also on the economic context where CSR perceptions are analyzed. Nevertheless, there is also a limitation of our study in this regard because we did not prove our model in diverse industries and so we cannot positively determine the adequacy of this proposal.

\section{REFERENCES}

Barone, M. J., Miyazaki, A. D., \& Taylor, K. A. (2000). The influence of cause-related marketing on consumer choice: Does one good turn deserve another? Journal of the Academy of Marketing Science, 28(2), 248-262.

Becker-Olsen, K. L., Cudmore, B. A., \& Hill, R. P. (2006). The impact of perceived corporate social responsibility on consumer behavior. Journal of Business Research, 59(1), 46-53.

Bigné, E., Chumpitaz, R., \& Currás, R. (2010). Alliances between brands and social causes: The influence of company credibility on social responsibility image. Journal of Business Ethics, 96, 169-186.

CECA. (2008). Libro verde de la responsabilidad social corporativa en el sector financiero. Conferencia Española de Cajas de Ahorro.

Clarkson, M. B. E. (1995). A stakeholder framework for analyzing and evaluating corporate social performance. The Academy of Management Review, 20(1), 92-117.

Ellen, P. S., Webb, D. J., \& Mohr, L. A. (2006). Building corporate associations: Consumer attributions for corporate socially responsible programs. Journal of the Academy of Marketing Science, 34(2), 147-157.

Flyvholm, P. E., \& Isaksson, M. (2008). Building credibility in international banking and financial markets: A study of how corporate reputations are managed through image advertising. Corporate Communications: An International Journal, 13(4), 365-379.

Forehand, M. R., \& Grier, S. (2003). When is honesty the best policy? The effect of stated company intent on consumer skepticism. Journal of Consumer Psychology, 13(3), 349-356. 
García de los Salmones, M. M., Herrero, Á., \& Rodríguez del Bosque, I. (2005). Influence of corporate social responsibility on loyalty and valuation of services. Journal of Business Ethics, 61(4), 369-385.

Goirigolzarri, J. I. (2006). La responsabilidad social en el sector financiero: el BBVA. Working paper, Fundación Carolina.

Goldsmith, R. E., Lafferty, B. A., \& Newell, S. J. (2000). The impact of corporate credibility and celebrity credibility on consumer reaction to advertisements and brands. Journal of Advertising, 29(3), 43-54.

Gwinner, K. P. (1997). A model of image creation and image transfer in event sponsorship. International Marketing Review, 14(3), 145-158.

Hoeffler, S., \& Keller, K. L. (2002). Building brand equity through corporate societal marketing. Journal of Public Policy\& Marketing, 21(1), 78-89.

KPMG. (2008). KPMG international survey of corporate responsibility reporting 2008. Netherlands: KPMG.

Lafferty, B. A. (2007). The relevance of fit in a cause-brand alliance when consumers evaluate corporate credibility. Journal of Business Research, 60(5), 447-453.

Lafferty, B. A., \& Goldsmith, R. E. (1999). Corporate credibility's role in consumers' attitudes and purchase intentions when a high versus a lowcredibility endorser is used in the ad. Journal of Business Research, 44(2), 109-116.

Lafferty, B. A., Goldsmith, R. E., \& Hult, G. T. M. (2004). The impact of the alliance on the partners: A look at cause-brand alliances. Psychology \& Marketing, 21(7), 509-531.

Lichtenstein, D. R., Drumwright, M. E., \& Braig, B. M. (2004). The effect of corporate social responsibilityoncustomerdonationstocorporate-supportednonprofits. Journal of Marketing, 68(4), 16-32.

Lynch, J., \& Schuler, D. (1994). The match up effect of spokesperson and product congruency: A schema theory interpretation. Psychology\& Marketing, 11(5), 417-445

Maignan, I., \& Ferrell, O. C. (2004). Corporate social responsibility and marketing: An integrative framework. Journal of the Academy of Marketing Science, 32(1), 3-19.

Maignan, I., Ferrell, O. C., \& Hult, G. T. M. (1999). Corporate citizenship: Cultural antecedents and business benefits. Journal of the Academy of Marketing Science, 27(4), 455-469.

Marín, L., \& Ruiz, S. (2007).“I need you too!” Corporate identity attractiveness for consumers and the role of social responsibility. Journal of Business Ethics, 71(3), 245-260.

Menon, S., \& Kahn, B. E. (2003). Corporate sponsorships of philanthropic activities: When do they impact perception of sponsor brand? Journal of Consumer Psychology, 13(3), 316-327. 
Mercer, J. J. (2003). Corporate social responsibility and its importance to consumers. Doctoral Thesis. Claremont Graduate University.

Nan, X., \& Heo, K. (2007). Consumer responses to corporate social responsibility (CSR) initiatives: Examining the role of brand-cause fit in cause-related marketing. Journal of Advertising, 36(2), 63-74.

Newell, S. J., \& Goldsmith, R. E. (2001). The development of a scale to measure perceived corporate credibility. Journal of Business Research, 52(3), 235-247;

Pérez, A. y Rodríguez del Bosque, I.A. (2012).The role of CSR in the corporate identity of banking service providers. Journal of Business Ethics, 108(2), 145-166.

Pomering, A., \& Johnson, L. W. (2009). Advertising corporate social responsibility initiatives to communicate corporate image. Corporate Communications, 14(4), 420-439.

Rifon, N. J., Choi, S. M., Trimble, C. S., \& Li, H. (2004). Congruence effects in sponsorship: The mediating role of sponsor credibility and consumer attributions of sponsor motive. Journal of Advertising, 33(1), 29-42.

Roy, D. P., \& Cornwell, T. B. (2003). Brand equity's influence on responses to event sponsorships. The Journal of Product and Brand Management, 12(6/7), 377-393.

Sarro, M. M., Cuesta, P., \& Penelas, A. (2007). La responsabilidad social corporativa (RSC): una orientación emergente en la gestión de las entidades bancarias españolas. In J. C. A. Calvo (Eds.), Conocimiento, Innovación y emprendedores: camino al futuro. Spain: Universidad de La Rioja.

Sen, S., Bhattacharya, C. B., \& Korschun, D. (2006). The role of corporate social responsibility in strengthening multiple stakeholder relationships: A field experiment. Journal of theAcademy of Marketing Science, 34(2), 158-166.

Server, R. J., \& Capó, J. (2009). La Responsabilidad Social Empresarial en un contexto de crisis. Repercusión en las Sociedades Cooperativas. CIRIEC-España, Revista de Economía Pública, Social y Cooperativa, 65, 7-31.

Soto, M. (2006). La responsabilidad social en el sector financiero: el Grupo SCH. Working paper, Fundación Carolina.

Till, B. D., \& Nowak, L. I. (2000).Toward effective use of cause-related marketing alliances. The Journal of Product and Brand Management, 9(7), 472-484.

van de Ven, B. (2008). An ethical framework for the marketing of corporate social responsibility. Journal of Business Ethics, 82(2), 339-352.

Van Marrewijk, M. (2003). Concepts and definitions of CSR and corporate sustainability: Between agency and communion. Journal of Business Ethics, 44(2/3), 95-105.

Weiner, B. (1980). Human motivation. Hillsdale, NJ: Lawrence Erlbaum Associates. 